\title{
The inclusion of Brazilian flight female nurses in the second world war: challenges and achievements
}

\author{
A inclusão de enfermeiras aeronautas brasileiras na segunda guerra mundial: desafios e conquistas \\ Inclusión de enfermeras aeronautas brasileñas en la segunda guerra mundial: desafíos y logros
}

Mariane Bonfante Cesário Lourenço ${ }^{1}$ Cecília Maria Izidoro Pinto ${ }^{1}$ Osnir Claudiano da Silva Junior ${ }^{2}$ Lúcia Helena Silva Corrêa Lourenço ${ }^{1}$ Graciele Oroski Paes ${ }^{1}$ Alexandre Barbosa de Oliveira ${ }^{1}$

1. Universidade Federal do Rio de Janeiro. Rio de Janeiro, RJ, Brazil.

2. Universidade Federal do Estado do Rio de Janeiro. Rio de Janeiro, RJ, Brazil.
Corresponding author:

Alexandre Barbosa de Oliveira.

E-mail: alexbaroli@gmail.com

Submitted on $01 / 12 / 2017$

Accepted on 02/23/2017.

DOI: 10.1590/2177-9465-EAN-2017-0008

\section{Abstract}

Objectives: To describe the circumstances of inclusion of female nurses in the Second World War through the Brazilian Air Force, and discuss the challenges faced by and the achievements of these nurses. Methods: Socio-historical study developed with textual and photographic sources, in addition to oral sources through interviews with war veterans. Data were treated according to the historical method and discussed with concepts support from the theory of social world, by Pierre Bourdieu. Results: The research has demonstrated that the inclusion of female nurses to the Air Force was characterized by social and symbolic effects of war demands and gender boundaries. Conclusion: The great challenge was the official incorporation of women by the Brazilian Air Forces in the post-war period. For this purpose, the organization of a flight female nurses cadre during the conflict was fundamental. Moreover, the record of this history reiterates the Nursing's legacy and the necessity of preparation for care in chaos situations.

Keywords: Nursing; Nursing History; Military Nursing; Second World War; Disasters.

\section{Resumo}

Objetivos: Descrever as circunstâncias da inclusão de enfermeiras na Segunda Guerra Mundial por meio da Força Aérea Brasileira; e discutir os desafios enfrentados bem como as conquistas alcançadas por essas enfermeiras. Métodos: Estudo histórico-social desenvolvido com fontes textuais, fotográficas e orais de entrevistas com veteranos de guerra. Os dados foram tratados em conformidade com o método histórico e discutidos com apoio de conceitos da Teoria do Mundo Social, de Pierre Bourdieu. Resultados: A pesquisa revelou que a inclusão de enfermeiras na Força Aérea foi caracterizada pelos efeitos sociais e simbólicos das demandas de guerra e dos limites de gênero. Conclusão: O grande desafio foi a incorporação oficial de mulheres nas Forças Armadas brasileiras, no pós-guerra. Para isso, foi fundamental a organização de um quadro de enfermeiras aeronautas durante o conflito. Ademais, o registro dessa história reitera o legado da Enfermagem e a necessidade de preparação para o cuidado em situações de caos.

Palavras-chave: Enfermagem; História da Enfermagem; Enfermagem Militar; II Guerra Mundial; Desastres.

\section{REsumen}

Objectives: Describir las circunstancias que rodean a la inclusión de las enfermeras en la Segunda Guerra Mundial por la Fuerza Aérea Brasileña, y discutir los desafíos y logros de estas enfermeras. Métodos: Estudio histórico y social desarrollado con fuentes textuales, fotográficas, y entrevistas orales con los veteranos de guerra. Los datos se procesaron de acuerdo con el método histórico, y discutieron con los conceptos de apoyo de la Teoría del Mundo Social, Pierre Bourdieu. Resultados: El estudio reveló que la inclusión de las enfermeras en la Fuerza Aérea se caracterizó por los efectos sociales y simbólicas de las demandas de los límites de guerra y de género. Conclusión: El mayor reto fue la incorporación oficial de la mujer en las fuerzas armadas de Brasil en la post-guerra. Para ello era importante organizar un personal de enfermería aeronautas durante e conflicto. Por otra parte, el registro de esa historia se repite legado de enfermería y la necesidad de prepararse para la atención en situaciones de caos.

Palabras clave: Enfermería; História de la Enfermería; Enfermería Militar; Segunda Guerra Mundial; Desastres. 


\section{INTRODUCTION}

In several countries, the necessity of structuring health services in the military forces' scope was argument for the use of female nurses in these culturally masculine spaces. Timely, the official incorporation of female nurses in military institutions has occurred mainly at moments of war, occasions recognized as important vectors of Nursing qualification. Such movement has contributed for the demarcation of the positions occupied by women in the military and social fields. ${ }^{1-3}$ For instance, such situation has occurred in Brazil during the Second World War (1939-1945).

In the context of this conflict, the Brazilian Air Force (FAB in the Portuguese acronym) was created in January 20, 1941, following the tendency of modern war of application and technological development of aircrafts, which would amplify the military conflicts to the airspace. ${ }^{4}$

Some months after this event, on August 31, 1942, state of war was declared in the whole national territory, which was specially motivated by the attack to 19 merchant vessels by the Nazis, situation that caused the death of 346 members of the crew and 410 passengers. On the occasion, one determined the use of aircrafts on the coast for search, rescue and radar patrol against German submarines. This placed Brazil beside the United States of America and, as consequence, beside the Allied countries, which included British Emperor, Soviet Union, China, Poland and France, among others, opposed to Germany, Italy and Japan, Axis powers that represented the Nazi-fascist powers of war.

The declaration of state of war by the Brazilian government was also motivated by political pressures from the United States of America, which aimed at the consolidation of the Pan Americanism and the Good Neighbor Policy. On the other hand, more than one hundred American aircrafts were brought in flight for basic instruction of Brazilian pilots, from 1942 to 1943, when one started articulating the creation of military and voluntary civil groupings, what was part of both the policy of national mobilization for war and the strategies of reoutfitting the Brazilian Military Forces and qualification of their contingent. ${ }^{5,6}$

This situation has allowed the creation of the FAB's $1^{\text {st }}$ Group of Jet Fighter Aircrafts, on December 18, 1943, by Decreelaw 6123, aiming at performing fighter aviation along with the Americans, in Europe. Then, one started the negotiations for the organization of the Health Service linked to the $1^{\text {st }}$ Group of Jet Fighter Aircrafts, which would be composed of voluntary female nurses and doctors to attend military combatants, pilots and support personnel.

To meet the standard of American allies, the Brazilian Air Force needed to incorporate female nurses in its cadre in order to organize its Health Service. Thus, one created the Aeronautics Reserve Force Nurses Cadre (QERA in the Portuguese acronym), through Decree 6663, dated July 7, 1944. With support from the Anna Nery School (EAN in the Portuguese acronym), one has selected six female nurses coming from this institution to compose the QERA, who were officially nominated, by the
Ministry of Aeronautics, as $2^{\text {nd }}$ lieutenant of $2^{\text {nd }}$ class reserve force. ${ }^{7}$ After military training in the United States, between July and September 1944, they boarded for Italy, being designated to two rear hospitals. During the war, they were responsible for the care of patients from the FAB's 1st Group of Jet Fighter Aircrafts, up to June $1945 .^{8}$

The creation of the QERA has contributed to minimize the gender division in the scope of the country's military forces. Albeit at the rear, Nursing was the way for the female inclusion in this space traditionally reserved for and occupied by men.

In light of the exposed, the objectives of this study were: to describe the circumstances of inclusion of female nurses in the Second World War through the Brazilian Air Force, discussing the challenges faced by and the achievements of these female nurses.

The relevance of this study is the possibility to provide greater knowledge and reflection on the unique history of these first female flight nurses in the country, whose cadre was organized and created with support from a School of Nursing. Registered in the field of Women's History, the study evidences the experience of a group of military nurses that are placed in the condition of History's object and subject, in the attempt to transpose the invisibility of their performance.

\section{METHODS}

It is a study of qualitative descriptive exploratory approach, of socio-historical nature, which aims at understanding determined moment, experienced by a human group in a specific spatial/ geographic profile.

The documental corpus encompassed historical, textual and photographic sources located in collections of the city of Rio de Janeiro: Anna Nery School of Nursing Documentation Center, National Library, Air Force Historic-Cultural Institute of Aeronautics, Army Historical Archive and Monument to the Dead of World War II.

To potentize the analysis, one has used the triangulation technique, through the articulation of textual and photographic sources, with the production of oral sources from narrative interviews with three war veterans that have participated of the FAB's $1^{\text {st }}$ Group of Jet Fighter Aircrafts, and were taken care of by QERA's members in the field hospitals, in Italy.

The Brigadiers José Rebelo Meira de Vasconcelos and Rui Moreira Lima, who were $2^{\text {nd }}$ lieutenant and acted as fighter pilots at the time of the conflict, have contributed to the study, and the Capitan Osias Machado da Silva, who served as soldier during the war. The interviews allowed amplifying the information on the daily living of the QERA's members in the hospitals, the interpersonal relationship with the patients and their professional practice.

These veterans were found at the monthly meetings of the FAB's $1^{\text {st }}$ Group of Jet Fighter Aircrafts, carried out in the Club of Aeronautics, in the city of Rio de Janeiro. Through Club's members, relatives and other FAB's soldiers, 46 individuals were identified as possible participants. However, only three 
individuals were able to be interviewed at the time of the data collection. Very advanced age, conditions of access to the residence, weakened health and difficulty of remembering the work of the QERA's members were determinant factors regarding the eligibility of veterans for the research.

In order to help the veterans' memory recall during the interviews development, pictures related to the topic were previously selected and used in the meetings, in order to increase the development of the thematic oral history technique.

Finally, the documental corpus of the study was compiled and classified thematically and temporally, criticized internally and externally, summarized and discussed in the light of concepts of the theory of the social world, by Pierre Bourdieu.

The limitations were related to the number of historic sources available on the theme. This lack of evidences is common when it is related to the women's past. Thus, great part of the sources found was marked by the masculine discourse, what, however, allowed us to identify symbolic elements that have supported a (re) reading of the experience of these nurses, by capturing the imaginary constructed on them, the rules that were imposed upon them, the militarization of their bodies and the assimilation of scenes of their daily living in war. ${ }^{9}$

Ethical and legal aspects have been duly considered in accordance with the Resolution no. 466, dated December 12, 2012, from the National Health Council, related to researches involving human beings, and with the Federal Law no.7524/1986, which sets forth the rules for the manifestation, by inactive military member, of political or philosophic thoughts and opinions. The study was approved by the Research Ethics Committee (Opinion 155.774, dated November 27, 2012).

\section{RESULTS AND DISCUSSION}

\section{The training of flight female nurses at American basis and hospitals}

With the advance of the Second World War, the Minister of Aeronautics, Joaquim Pedro Salgado Filho, requested the support from the EAN for organization and creation of the QERA. The invitation occurred due to the obtainment of the title of Official Standard School for formation of nurses in Brazil, by means of the Decree no. 20109, dated $1931 .{ }^{7}$

In the regulation for creation of the QERA, one sought to assure to the future participants the concession of $2^{\text {nd }}$ lieutenant positions; similar fact occurred with the American military organizations, where the right to military positions for female nurses was assured. Such strategy would place the Brazilian female nurses in equal conditions regarding the male nurses in military field, inedited situation in the country up to that date, achievement that has represented a symbolic gain to the Nursing profession. ${ }^{8}$

One has selected six nurses aged 24-47 years: three from Rio de Janeiro (Izaura Barbosa Lima, coming from the first class of the EAN and founder of the National Association of Brazilian Certified Nurses, current Brazilian Nursing Association; Judith
Arêas and Ocimara Moura Ribeiro), two from the North region (Maria Diva Campos and Regina Cerdeira Bordallo) and one from the Northeast region (Antonina Hollanda Martins).

The Health Service of the FAB's $1^{\text {st }}$ Group of Jet Fighter Aircrafts also counted on the incorporation of four doctors, among them the orthopedist Lutero Sarmanho Vargas, son of the then President of the Republic, Getúlio Dornelles Vargas. The air boarding for the war activities happened on July 12, 1944, at the Santos Dumont Airport, Rio de Janeiro.

The female nurses were lodged in the United States Mitchel Air Force Base, in Long Island (New York), where were received by the $1^{\text {st }}$ lieutenant Joella Wallace, liaison officer designated to promote the adaptation of the Brazilian nurses to rules, routines and language. To help them, Clara Louise Kieninger, EAN's first director (1922-1925 administration), intermediated the reception of the Brazilian nurses in some situations, in order to achieve social success regarding the inclusion of the nurses in a bureaucratic field with different working conditions and practices, to which they were not used. ${ }^{10}$

Most part of the nurses' military training was developed by two sergeants, one Brazilian and one Portuguese naturalized North American. There were classes of marches, physical instruction, continence, pistols handling, use of incendiary bombs, fire extinguishing, defense against chemical agents, technique of decontamination of clothes, collective shelters, means of transportation, techniques for the use of gas masks, recognition of different types of aircrafts, swimming in pool and sea, defense of the military lost in the forest, techniques of camping, evacuation and transport of the wounded by air, location of reservoirs, origin, conservation and treatment of water.

Izaura Barbosa Lima stood out as leader of the group. In her report, the nurse has criticized the excessive number of classes spent for activities that would not be so necessary in the field hospitals. They were classes for militarization of body and mind, in order to standardize gestures, positions and conducts, aiming at the accomplishment of military affairs. For the nurse, other themes would be more relevant, there being need of greater number of classes, more directed to the Nursing know-how, such as: evacuation of the wounded, air transport and care for the environment. Nevertheless, the training performed was in line with the military corporations' efforts for the incorporation of a own socially constructed habitus, which tends to forge an identity for its soldiers well fitted to practices and ideologies of this field, what, in certain circumstances, may favor the military formation rather than the technical one. ${ }^{11}$

The result is that the specificity of the bureaucratic fields is in the ability to assure that their incumbents reproduce all practices inscribed in the definition of the position, through the direct and visible effect from regulations and guidelines, and, above all, through the set of mechanisms of vocation-approach that contribute to adjust the agents to their positions or, more precisely, their attitudes to their positions; and, then, to ensure that those practices are recognized as statutory authority. ${ }^{11}$ 
Several technical visits to civil and military hospitals of different sizes and specialties were performed in parallel with the training. Moreover, professional internships were developed for six weeks at the Mitchel Air Force Base's hospital. This helped the Brazilian nurses regarding the adaptation to rules, routines, work dynamics and procedure techniques used by the American health service, situation ratified by the veteran Osias Machado da Silva, who reported that "they spent this time adapting themselves to everything, including the American medication."

It is verified that this contact with new care technologies was fundamental for the Brazilians' better performance in war. For it was in the core of the Second World War that new procedures in health field were broadly tested and introduced in the country, as the use of penicillin by intravenous route, which was widely used in the treatment of bacterial infections of injured soldiers. By the way, the medication was strategic instrument of propaganda and politics, a technological heritage that would excessively affect a future pharmaceutical and therapeutic development, as well as the power relations in the health field. ${ }^{12}$

The nurses have also visited the school located in the Lincoln Hospital, exclusive for black students, who were trained to take care exclusively of black people. Certainly, the racial segregation in the United States at the time included the care spaces as well. The discrimination of foreigners, mainly Asian and Latin people, was common. These marks would extend to the field hospitals, what was visible in the previous process of alliance between Brazil and the United Sates, when the American military command requested that the mixed-race Brazilian nurses took care specifically of mixed-race Brazilian soldiers. This is indicated by one of the veterans interviewed:

\section{[...] When Brazilian soldiers came to the hospital, naturally they were not taken care of by the American nurses. Some soldiers of ours were attended by Americans, upon request. [...] But, in general, our nurses attended only Brazilians, because they went to the war to take care of us [...] (Brigadier Rui Moreira Lima)}

The non-observance of fundamental principles of Nursing practice, that is, care delivery without distinction, it being also target of recommendations of the International Red Cross at the time, represented heretical deviance of care that impelled and adjusted the tragic detachment of people in function of the skin color, from alienating believes and hierarchies. This was translated into a great paradox, since the war against the Nazifascist powers was also based on the repugnance to violent acts due to race, culture and social origin. ${ }^{13}$

On September 5, 1944, the nurses left the Mitchel Air Force Base and went to the Suffolk County Army Air Field, in Virginia, being incorporated in the FAB's $1^{\text {st }}$ Group of Jet Fighter Aircrafts. Finally, in September 19, in the city of Newport, they boarded for Italy. In addition to the $1^{\text {st }}$ Group of Jet Fighter Aircrafts, the ship transported the $92^{\text {nd }}$ Infantry Division, whose components were known as buffalo soldiers, due to their skin color similar to the buffalo's. This Division was formed by Afro-American soldiers, who have fought in the First World War, and now was going to the Second World War. ${ }^{8}$ On this journey, the Brigadier José Rebelo Meira de Vasconcelos, fighter pilot at the time, made the following statement: [...] "They gathered everybody on a ship.There were about one thousand people. All of us of the $1_{\text {st }}$ Group of Jet Fighter Aircrafts, plus a bunch of Americans"[...].

The spatial separation of Latinos and Afro-Americans from the other white soldiers indicates that, even if the components of the FAB's $1^{\text {st }}$ Group of Jet Fighter Aircrafts were social, cultural, professional and symbolic capital holders - exchange currency that could allow some distinction -, the Latin condition, for the Americans, already put them in a socially disadvantaged position, despite the symbolic manipulation strategies of the United States Government to fraternize Brazilians and Americans during the war, through the Good Neighbor Policy and the Pan Americanism. ${ }^{14}$ Symptomatically, politics is the place, by excellence, of symbolic efficacy, action that is exercised by signals and strategies able to produce social things and, above of all, give or not distinction to certain groups. ${ }^{11}$

Under this vision, in the symbolic fight for power and definition of the order in the fields in question, the stereotypes of race, sociocultural status and region of origin tend to be symbolic elements, which determine the principles of classification among the agents. This fight of classifications is the fight for the definition of identity, for the monopoly of being seen and believed, of revealing and recognizing, of imposing the legitimate definition of the social world divisions and, through it, create groups and undo them. ${ }^{15}$

In fact, the dominant culture, whose power is based on economic capital, contributes for the real integration of the dominant class, through the establishment of the distinctions (hierarchies) and of the legitimation of these distinctions, compelling all cultures (designated as subcultures) to define themselves by their distance regarding the dominant culture. ${ }^{11}$

After 16 days of maritime traffic and 13 hours by train, the group got off under torrential rain in Civitavecchia. The Brazilian nurses should be wearing winter uniforms, what would avoid the discomfort. Nevertheless, the liaison officer Joella Wallace emphasized the "good spirit" of the Brazilians, who were not let down by the difficult situation. ${ }^{10,8}$

\section{The Brazilian flight nurses at American field hospitals, in Italy}

Before they arrived in Civitavecchia, the FAB's nurses and doctors went to the $154^{\text {th }}$ Station Hospital, where worked temporarily, from October 7 to December 12, 1944. In this hospital, 12 American nurses have already been allotted, in addition to the six newcomer Brazilians. All of them had half a day off a week and a full day every two weeks; however, any time off was suspended according to the service needs.

On the occasion, the Brazilian nurses started facing the lack of service materials necessary for personal use, when they requested the liaison officer to obtain the approval from the 
hierarchic superiors for the use of Americans nurses' uniforms, because the white uniform they had received was not proper to the service, cold and the conditions of lack of laundry material.

After this period, The Brazilians left for the $2^{\text {th }}$ General Hospital, in Livorno. There, they found three nurses organized for the attendance of clinical and surgical cases from the $1^{\text {st }}$ Group of Jet Fighter Aircrafts.

In the war, the American field hospitals followed the standard-type organization, whose service was standardized and systematized according to the gravity of the cases, injured quantity and location in relation to combat fronts. As the conflict forced the troop to change stations, it was sought to direct the best locations and buildings for the Health Service installations. The evacuation chain was structured by crescent complexity, as follow: First Aid, Field Hospital, Station Hospital and General Hospital.

Despite the dramatic war scenario, the nurses sought to promote a comfortable and welcoming environment for the soldiers-patients. On this, one of the airmen, who was injured in one of the hospitals, affirmed: [...] "So... The problem was to make the environment the most calm possible." [...] (Brigadier Rio Moreira Lima). Another veteran remembered the friendly environment of the hospital, when watching a picture during the interview with the flight nurses: [...] "You always notice the joy!" [...] (Capitan Osias Machado da Silva).

The oral sources, related to the textual and photographic ones, endorse the idea that the nurses would have sought to promote well-being during the war, in the sense of minimizing concerns, minimizing the great stress and psychic suffering, avoiding negative thoughts and keeping the good mood (Figure 1). Some pictures, with free dedication-type writings (Figure 2), register Nursing care provided at the hospital and give evidences of both this friendly relationship and the affection of QERA's members regarding their patients:

It is possible that the written messages on the back of the pictures are an attempt to minimize the suffering and the stress caused by being experiencing an armed conflict. Despite the limited resources available and the stigma about the psychiatric treatments at the time, the stimulus to the development of interpersonal and interactive relationship was an important tool to attenuate the loneliness and suffering, and had and essential role for resilience, health promotion and care effectiveness. ${ }^{16}$

However, routines and regulations determined the functioning of the infirmary in the field hospitals, since there were rights and duties to be met by professionals and soldiers-patients. Strategically, the control and the cleanliness of the nosocomial environment were fundamental, in order to prevent the dissemination of pathologies and deteriorating health. Thus, there were measures as the prohibition of towels and personal hygiene objects sharing, and patients that were in better health conditions should keep their beds cleaned and organized. Such practices refer to the recommendations of Florence Nightingale in the Crimean War (1853-1856), and to the practical and symbolic effects of the development of her Environmental Theory. ${ }^{17}$
Figure 1. Nurses and other soldiers of the FAB's $1^{\text {st }}$ Group of Jet Fighter Aircrafts - $12^{\text {th }}$ General Hospital, Livorno, 1944. Source: Instituto Histórico Cultural da Aeronáutica, Rio de Janeiro.

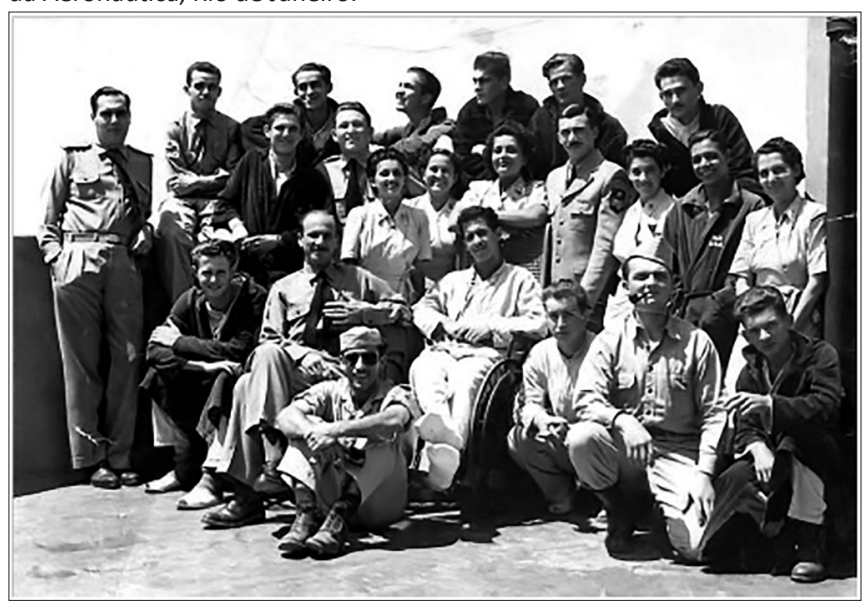

Figure 2. Verses of photographs with dedications of QERA members to their patients. Source: Instuto Histórico-Cultural da Aeronáutica, Rio de Janeiro.

\begin{tabular}{|c|c|c|}
\hline 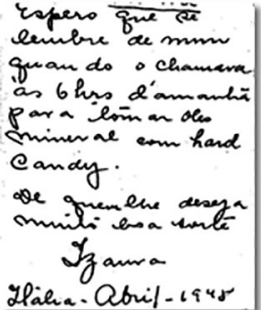 & 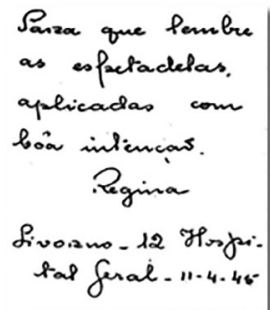 & 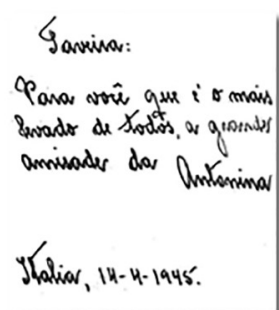 \\
\hline
\end{tabular}

Thus, the occurrence of respiratory diseases due to low temperatures and indiscriminate use of cigarettes, as well as the high incidence of sexually transmitted infections, mainly syphilis, were considered as a species of "enemy" that make the young soldiers injured in hospitals, incapacitating them to fight, as in the following report: [...]"Oh, yes! They got a cold, they got I do not what... And they went to hospital [...] I have not had a serious disease... I've caught a bad flu... It was not a venereal disease! It was coryza..." [...] (Brigadier Rui Moreira Lima)

In the stressing war scenario, other health issues affected the soldiers, such as hypothermia, trauma, hemorrhage, shock, fractures, post-traumatic stress, among others, what required the nurses and doctors to have specific skills and abilities to achieve effectiveness in their interventions. In this sense, the following excerpts show other aspects on professional and symbolic capital accumulated by the QERA's members during their professional performance in the hospitals:

[...] On these girls... The care that they provided for us in the hospital was amazing! A huge coziness! [...] What that most attracted attention to them was the politeness, and next, the way they acted... They seemed to be one! Then, we think... I want to tell that Anna Nery School was really a professionals' school. [...] (Brigadier Rui Moreira Lima) 
[...] They were well-respected nurses! I remember very well... All of them wearing warm clothes, all tidy... They were not any nurses.... I have met many nurses from Brazil, who were people that only knew how to apply an injection or apply Mercurochrome on a cut... But, it was not their case! They were really competent! They had formation. They have helped us a lot! [...] (Capitan Osias Machado da Silva)

In the excerpts, the recognition of the competence of the QERA's members is reiterated, but also the valorization of EAN's nurse certification. Emblematically, the guarantee of the "Anna Nery Standard" remained in the interviewed veterans' memory, and was reproduced 70 years later, demarcating in their discourses the distinctions produced by the school titles, which tend to produce or reinforce, in the individuals, the belief in the naturalization of differences. ${ }^{18}$ This school capital obtained, and possibly the familiar and cultural capital inherited, were exchange currency for the group's value acknowledgment, what assured a differentiated relationship that was expressed by certain concordance regarding their inclusion in that field. ${ }^{19,11}$

These discourses somehow manifest that the QERA's members have succeed in relation to the work developed in the field hospitals in Italy, but also tend to prove the success of the particular strategies used by the EAN's leaders at the time, to be seen and recognized as a high standard institution in formation of nurses in the country. ${ }^{7}$

However, some limits related to the gender question have influenced the occupation of some social spaces by nurses in that context. Although they officially used the position of $2^{\text {nd }}$ lieutenant and, consequently, were in hierarchical conditions practically similar to their masculine peers, they have faced some restrictions. Such situation is reported as follow:

\section{[...] So... Sometimes one came.... Because.... A woman there.... There were only men in the war! Then, it was a bad deal for them... They came, but there was a separated place for them... Normally, they always stayed at the hospital, attending people there. [...] (Brigadier José Rebelo Meira de Vasconcelos)}

The excerpt illustrates the fact that, in that field, the presence of women midst men was something unusual and unnatural, what reinforces the idea of their segregation from certain social spaces and practices. With effect, the places of interaction are pre-constructed, that is, they have a social composition previously determined by the laws of formation of the group itself, which defines who excludes and who must be excluded, what turns consent into the most radical censure. In the perception of those veterans, even if temporally distant from the years of war and possibly already influenced by new mentalities, the idea that the nurses needed to be apart from determined places, and even absent from others, has remained. ${ }^{11}$
In this aspect, the masculine domination, which considers the woman as a symbolic object, has the effect of placing them in permanent state of symbolic dependency: They exist at first by and for the other's vision. It is expected from them that they are "feminine," that is, friendly, smiling, attentive, submissive, maidenlike, discrete, housewife. As consequence, the dependency regarding others tends to be constitutive of her being.

On the other hand, the acknowledgment of the professionalism of the QERA's members was object of the interviewed veterans' mental representation, as it seems to be. The following speech represents this idea:

\section{[...] They wanted to show the maximum as possible! They wanted to show that were good professionals. There, there were not women! There were professionals! And I have heard the favorable comments from the fellows on this. [...] So, the dispatch of those nurses to war has helped us a lot! [...] It was a happy idea! [...] (Capitan Osias Machado da Silva)}

Possibly, for the military of the $1^{\text {st }}$ Group of Jet Fighter Aircrafts, the presence of those nurses in the hospitals was translated into the comforting idea of being supported and under care. By the way, it seems that the feminine presence in wars had this capacity to make the injured and dying soldiers refer to their home, reproducing the noble roles of their grandmothers, mothers, aunts, wives and daughters. Seen by this angle, the dedication to the care of men in war made them to enter the game by proxy, through the men, consciously or not, leading them to contribute for their own inclusion regarding social spaces where they are systematically excluded. ${ }^{20}$

\section{The termination of war and the return of the nurses to Brazil}

In Europe, the war finished on May 8, 1945, when the Victory Day was declared. Before boarding for Brazil, the QERA's members, in interview to the Associated Press, expressed the desire of collaborating with the American nurses, who would continue their activities in the Pacific Theater Operations, fighting Japan. This was also reported by the Brazilian press through Jornal A Noite and Jornal do Brasil (Brazilian newspapers), on July 27, 1945. Despite the manifested desire, the Brazilians returned to the country accompanied by the $1^{\text {st }}$ tenant Joella Wallace.

When arriving, all the QERA's members received furlough from the Active Military Service of Aeronautics, and were excluded from the $1^{\text {st }}$ Group of Jet Fighter Aircrafts, by ministerial order. ${ }^{8}$ Izaura Barbosa Lima retook her position as head to the Nursing Section of the Sanitary Organization Division of the National Public Health Department; Regina Cerdeira Bordallo, Ocimara Moura Ribeiro and Maria Diva Campos were contracted as civilians by the Central Hospital of Aeronautics; Antonina 
Hollanda Martins returned to work at the EAN; and Judith Arêas started working in the Central Hospital of Aeronautics, but linked to the EAN.

In global scope, the Second World War has helped to create opportunities for significative Nursing advances in social and scientific fields, what favored its professionalization and dissemination of favorable representations in the pots-war period, such as, for instance, through legitimate discourses on the development of scientific principles and Nursing Theories.

In Brazil, a few initiatives were developed by the Army Forces to use the professional capital accumulated by the flight female nurses in war. Meanwhile, in allied nations, the activities of reconversion to piece times had been already carefully studied since the termination of war.

Years later, the Brazilian Nursing Association (ABEN in the Portuguese Acronym) published a note in the section "Legislation," in the Brazilian Nursing Magazine, dated June 1958, which emphasized some projects in progress in the Federal Chamber, among them the Bill 2817/1957, which aimed at the reinclusion of the QERA's nurses in the Active Military Service of Aeronautics.

Such achievement was only reached 14 years after the termination of war, in political partnership with the Congressman Lutero Sarmanho Vargas and in the country's democratic context. Thus, on September 10, 1959, the Law 3.632 was promulgated, right after debates timely carried out during the $2^{\text {nd }}$ Congress of Military Medicine, in August 1959, where ABEn's representatives participated of this discussion. In this event, the creation of a high standard feminine Nursing cadre within the Army Forces was proposed, such as the career cadres for the American nurses.

The law has assured to the QERA's members the resumption of the position of $2^{\text {nd }}$ lieutenant, the permanence in lines up to the limit age, the transference to the paid reserve after 25 years of service, the enjoyment of rights, advantages and perquisites inherent to Aeronautics' active officers, except the access to higher hierarchical positions, the limit being the position of $1^{\text {st }}$ lieutenant. This legal gain seemed to be enough for the context, especially if the symbolic force and the traditional structure of the military field were considered, which had well-delimited limits for the access of women.

Only three out of six QERA's members requested the reinclusion: Maria Diva Campos, who started acting as head nurse to the ambulatories of the Central Hospital of Aeronautics; Ocimara Ribeiro, who has worked at the Surgical Center of the Galeão Air Force Hospital; and Antonina de Holanda Martins, who worked as head nurse to this hospital, but requested license in April 1963, when started integrating the EAN's Faculty. The other three have not requested convocation. Regina Cerdeira Bordalo has moved to the United States; Izaura Barbosa Lima has continued her activities in the Ministry of Health scope; and Judith Arêas, who passed away in 1953, before the law promulgation. ${ }^{8}$

Despite the reinclusion of the nurses has been an important precedent for the effective ingress of feminine segments in the country's Armed Forces, what happened in the scope of the
Brazilian Army in the same political-social context, they kept on being the only living example of feminine presence in this field up to the 1980s. ${ }^{8,21}$ Such situation was redefined only in the last years of the Military Dictatorship (1964-1985), when, due to the crisis in the government and the movement of re-democratization of the country, one initiated the planning of incorporation of feminine segments to "sweeten" the outworn image of the military institutions at the time. Moreover, it is in the logic of the symbolic exchanges economy that the social status of exchange "objects" is determined for women, according to the masculine interests, what tends to be incorporated in the political games.

In spite of this, by having worked at the Health Service of the Fab's $1^{\text {st }}$ Group of Jet Fighter Aircrafts during the war and having been reincluded in the Active Military Service of Aeronautics in 1959 , these nurses have contributed to amplify the visibility of the woman and the Nursing itself, in military and social fields. The group, in spite of small, has printed material and symbolic marks of the school capital, legitimated by the Nursing certificate, as well as aggregating the military and symbolic capitals to the professional capital, accumulated by the inedited official performance of Brazilian nurses in a great world war

\section{FINAL CONSIDERATIONS}

The historical sources located and produced throughout this study have met the objectives proposed, revealing that the inclusion of FAB's nurses was characterized by the social and symbolic effects of the war demands and gender boundaries at the time.

In summary, among the results achieved, one emphasizes the identification of several challenges that were faced by the QERA's members during their performance in war, as the language barriers, hurried training, necessity of incorporation of military habitus and adaptation to the field, origin and racial restrictions, gender questions and boundaries, long and hard journeys, rigorous winter, lack of materials of personal use and supplies for the service, the intense work load in the hospitals and the multiculturalism in the work environment.

Therefore, the challenges that most express the war context were the adjustment to new care technologies, ethical dilemmas assistance, intense service scales, diverse and complex health issues developed by the patients, transportation of the soldiers, and the drama of the conflict. Ultimately, the responsibility to represent the Brazilian Nursing in large American field hospitals and the demobilization and consequent exclusion from the military field in the post-war period perhaps have been the challenge that exceeded the frontiers/limits of war. However, the precarious (re) cognizance of their historic performance has called attention, what this study sought to minimize.

Thus, the pioneering performance - and inspired in the American standard of the first flight nurses of the country -, whose cadre was organized and created with support from a School of Nursing, may be understood as the first example in order to today, after fights, advances and regression, there be concretely 
feminine officers and soldiers cadres in the scope of the Brazilian Armed Forces, what has minimized the gender division of the work in the scope of military institutions, which have never incorporated women in their personnel cadres. Albeit at the rear, the Nursing turned itself into a way for feminine insertion in this space traditionally reserved for and occupied by men.

Currently, there are new challenges for Nursing due to the maintenance of certain limits to the profession in the military field, as the difficult access to the maximum position in the nurses' career, what is conceived only to certain professional groups, as well as the necessity of technical preparation to better response in situations of disaster. Nevertheless, the history of the QERA's members reinforces the legacy of the fundamental necessity of Nursing in chaos scenarios, aiming at the humanitarian assistance and at one of its most basic functions, saving lives.

\section{ACKNOWLEDGEMENT}

To the Coordination for the Improvement of Higher Education Personnel for the Master Degree's scholarship, to the National Council for Scientific and Technological Development (Universal Call - MCTI/CNPq № 14/2013) for the research financing, and to the veterans of the FAB's $1^{\text {st }}$ Group of Jet Fighter Aircrafts, and to the nurse Leila Milman Alcântara (in memoriam) for the contributions.

\section{REFERENCES}

1. Makita Y. Professional Angels at War: The United States Army Nursing Service and Changing Ideals of Nursing at the Turn of the Twentieth Century. Jpn J Am Stud [Internet]. 2013; [cited 2016 Jul 1]; 24:67-86. Available from: http://jaas.gr.jp/doc/2013/04Makita.pdf

2. McDonald L. Florence Nightingale, statistics and the Crimean War. J R Stat Soc Ser A Stat Soc [Internet]. 2014 Jun; [cited 2016 Jul 1]; 177(3):569-86. Available from: http://onlinelibrary.wiley.com/ doi/10.1111/rssa.12026/abstract. DOI: 10.1111/rssa.12026

3. Thébaud F. Penser les guerres du XXe siècle à partir des femmes et du genre: quarante ans d'historiographie. Clio [Internet]. 2014; [cited 2016 Mar 3]; 39:157-82. Available from: www.cairn.info/revue-clio-femmesgenre-histoire-2014-1-page-157.htm

4. Jasper FNH. Aeronáutica, Força Aérea ou Comando da Aeronáutica? Rev UNIFA. 2013;26(32):59-67.

5. Freire Junior O, Silva I. Diplomacy and science in the context of the World War II: Arthur Compton's 1941 trip to Brazil. Rev Bras Hist [Internet]. 2014 Jun; [cited 2016 Jul 19]; 34(67):181-201. Available from: http://www.scielo.br/scielo.php?script=sci_arttext\&pid=S010201882014000100009\&lng=en\&nrm=iso\&tlng=en. http://dx.doi. org/10.1590/S0102-01882014000100009
6. Godoy TRP, Calaza CP. A formação da "pródiga filha alada" de Getúlio Vargas e suas primeiras façanhas em um conflito mundial (1941-1945). Rev UNIFA. 2013;26(33):46-58.

7. Oliveira AB, Cesário MB, Santos TCF, Orichio APC, Abreu MSA. Qualified nurses for the air force: the organization of a military group for the Second World War. Texto contexto- Enferm. [Internet]. 2013 Sep; [cited 2016 Jul 19]; 22(3):593-602. Available from http://www.scielo.br/scielo.php?script=sci_arttext\&pid=S010407072013000300004\&lng=en\&nrm=iso\&tlng=en. http://dx.doi. org/10.1590/S0104-07072013000300004

8. Cansanção E. Um! Dois! Esquerda! Direita! Acertem o passo! Maceió: Cian; 2003. 270 p.

9. Cardoso CF, Vainfas R. Domínios da História: ensaios de teoria e metodologia. $2^{a}$ ed. Rio de Janeiro: Elsevier; 2011. 508 p.

10. Wallace JRN. With the first Brazilian fighter squadron. Am J Nurs [Internet]. 1946 Jun; [cited 2017 Jul 21]; 46(6):371-2. Available from: http://journals.Iww.com/ajnonline/Citation/1946/06000/With_the_First_ Brazilian_Fighter_Squadron_.6.aspx

11. Bourdieu P. O poder simbólico. 16 $6^{\underline{a}}$ ed. Rio de Janeiro: Bertrand Brasil; 2012. $322 p$

12. Capocci M. Cold drugs. Circulation, production and intelligence of antibiotics in post-WWII years. Med Secoli [Internet]. 2014; [cited 2016 Nov 1]; 26(2):401-22. Available from: https://www.ncbi.nlm.nih.gov/ pubmed/26054208

13. Zroka AL. Serving the Volksgemeinschaft: German Red Cross Nurses in the Second World War [PhD Thesis]. San Diego: University of California; 2015. 544 p. Available from: http://escholarship.org/uc/item/88m8c64r

14. Rosenheck U. Philatelic Remembrances: Stamps, National Identity, and Shifting Memories of WWII in Brazil. Lat Am [Internet]. 2016 Mar; [cited 2016 Jul 1];60(1):115-37. Available from: http://onlinelibrary.wiley.com/ doi/10.1111/tla.12066/full

15. Bourdieu $P$, Wacquant $L$. Sobre as artimanhas da razão imperialista. Estud Afro-Asiát [Internet]. 2002; [cited 2016 Jul 1]; 24(1):1533. Available from: http://www.scielo.br/scielo.php?script=sci arttext\&pid=S0101-546X2002000100002. http://dx.doi.org/10.1590/ S0101-546X2002000100002

16. Lavallee S. Enduring Casualties of War: Delayed Treatment of Combat Stress in World War II Veterans. Fairmount Folio: J Hist [Internet]. 2012; [cited 2016 Jan 13]; 14:82-118. Available from: http://journals.wichita. edu/index.php/ff/article/view/141/148

17. Shetty AP. Florence Nightingale: The queen of nurses. Arch Med Health [Internet].2016; [cited 2016 Aug 4]:4(1):144-8. Available from: http://www. amhsjournal.org/temp/ArchMedHealthSci41144-5204532_142725. pdf. DOI: 10.4103/2321-4848.183362

18. Silva Junior OC. PAN - Padrão Anna Nery: a instituição da identidade profissional da enfermeira no Brasil [Tese de doutorado]. Rio de Janeiro (RJ): Escola de Enfermagem Anna Nery, Universidade Federal do Rio de Janeiro; 2000. 178 p.

19. Bourdieu P. A Distinção: Crítica Social do Julgamento. São Paulo: Edusp; 2007. 560 p.

20. Bourdieu P. A Dominação Masculina. $3^{a}$ ed. Rio de Janeiro: Bertrand Brasil; 2003. 160 p.

21. França LS, Progianti JM, Baptista SS. A inserção de enfermeiras militares na Força Aérea Brasileira (1981-1982). Rev Enferm UERJ [Internet]. $2010 \mathrm{Jul} / \mathrm{Sep}$; [cited $2016 \mathrm{Jul}$ 01]; 18(3):371-3. Available from: http://www.facenf.uerj.br/v18n3/v18n3a06.pdf 